\title{
The distribution and profile of nutrients and catechins of some Indonesian seaweeds
}

\author{
JOKO SANTOSO, ${ }^{1,2}$ YUMIKo YOSHIE, ${ }^{1}$ AND TAKESHI SUZUKI ${ }^{1}$ \\ ${ }^{I}$ Department of Food Science and Technology, Tokyo University of Fisheries, Minato, Tokyo 108-8477, Japan \\ (fd00508@cc.tokyo-u-fish.ac.jp), ,2Department of Fisheries Processing Technology, Bogor Agricultural University, \\ Darmaga, Bogor 16680, Indonesia
}

KEY WORDS: catechin, dietary fiber, fatty acid, Indonesian seaweeds, mineral

\section{INTRODUCTION}

As foodstuff sources, seaweeds have high nutritional value as source of minerals, dietary fibers, fatty acids, and free amino acids ${ }^{1-4)}$ and also potential source of antioxidant compound like catechin. ${ }^{5,6)}$ Indonesia is an archipelago country, having large number of seaweeds. The potential of seaweeds resources is estimated at 482,400 ton/year. ${ }^{7)}$ However the utilization up to present is limited to a few species. Furthermore research activity about them is rare and still fertile area. Therefore we studied this research to obtain data about the distribution and profile of nutrients and catechin of some Indonesian edible seaweeds.

\section{MATERIALS AND METHODS}

Six species of Indonesian edible seaweeds were used in this experiment. Two green algae (Caulerpa sertularoides (CS), and Caulerpa racemosa (CR)), three brown algae (Turbinaria conoides (TC), Sargassum polycystum (SP), and Padina australis (PA)), and one red alga (Kappaphycus alvarezii (KA)) were collected from Seribu Islands, Jakarta Prefecture. After removing sand, the seaweed samples were washed with clean seawater and transported to the laboratory under refrigeration. After washing with tap water and wiping with paper towel, seaweed samples were minced by a food cutter (MK-K75; Matsushita Electric Corp., Osaka, Japan), and stored at $-20^{\circ} \mathrm{C}$ until used. Moisture, ash, and protein contents were determined according to $A O A C^{B)}$, whereas fat was extracted with methanol and chloroform according to the method of Bligh and Dryer. ${ }^{9)}$ Mineral and fatty acid contents were analyzed by an atomic absorption spectrophotometer and a gasliquid chromatograph, respectively. Soluble and insoluble dietary fibers were determined according to the enzymatic gravimetric method, ${ }^{4)}$ whereas the seaweed catechins were extracted and determined according to the modified method for tea catechins. ${ }^{1(1-12)}$

\section{RESULTS}

Proximate composition, mineral contents and fatty acid composition of the seaweed samples are presented in Table 1.

Table 1 Proximate, mineral contents, and fatty acids composition of Indonesian edible seaweeds.

\begin{tabular}{|c|c|c|c|c|c|c|}
\hline & \multicolumn{6}{|c|}{ Seaweeds Species } \\
\hline & $\mathrm{CS}$ & CR & $\mathrm{TC}$ & SP & $\mathrm{PA}$ & $\mathrm{KA}$ \\
\hline & \multicolumn{6}{|c|}{ Proximate composition (mean $=\mathrm{SD} \mathrm{g} / 100 \mathrm{~g}$ ) } \\
\hline Moisture & $82.39 \pm 0.62$ & $88.76 \pm 0.54$ & $85,05 \pm 0.34$ & $84.67 \pm 0.37$ & 83.0840 .95 & $83.28 \pm 0.64$ \\
\hline Ash & $2.86 \pm 0.30$ & $2.14 \times 0.23$ & $2.50 \pm 0.08$ & $3.83 \div 0.26$ & $5.47 \pm 0.35$ & $3.37 * 0.09$ \\
\hline Fat & $2.26 \pm 0.12$ & $0.53 \pm 0.02$ & $0.75 \pm 0.05$ & $0.33 \pm 0.02$ & $0.75 \pm 0.12$ & $4.15 \pm 0.11$ \\
\hline \multirow[t]{2}{*}{ Protein } & $3.05 \pm 0.18$ & $1.45 \pm 0.16$ & $1.04 \pm 0.11$ & $0.91 \pm 0.02$ & $1.48 \pm 0.03$ & $0.74 \pm 0.05$ \\
\hline & \multicolumn{6}{|c|}{ Mineral contents (mean $\pm \mathrm{SD} \mathrm{mg} / \mathrm{g}$ dry weight) } \\
\hline $\mathrm{Cu}$ & . & . & - & $0.01 \pm 0.01$ & . & . \\
\hline $\mathrm{Fe}$ & $0.03 \pm 0.01$ & $0.10 \pm 0.06$ & . & $0.13 \pm 0.02$ & $0.2 .3 \pm 0.05$ & . \\
\hline $\mathrm{Zn}$ & . & - & $0.02 \pm 0.01$ & $0.01 \pm 0.01$ & $0.01 \pm 0.005$ & $(0.01 \pm(1.00)$ \\
\hline $\mathrm{Mg}$ & $3.68 \pm 1.03$ & $3.84 \pm 0.32$ & $5.74 \pm 0.26$ & $5.69 \pm 0.66$ & $4.04 \pm 1.5 k$ & $2,88 \pm 11,34$ \\
\hline $\mathrm{Ca}$ & $11.95 \pm 4.43$ & $18.52 \pm 5.30$ & $14.74 \pm 2.17$ & $18.67 \pm 1.44$ & $2 B .31 * 4.26$ & $2.8(k) \pm 1), 31$ \\
\hline K & $2.50 \pm 0.37$ & $3.18 \pm 0.22$ & $27.92 \div 1.08$ & $17.54 \pm 1.35$ & $2.59 \pm 0.40$ & $87.10 \pm 5.83$ \\
\hline \multirow[t]{2}{*}{$\mathrm{Na}$} & $29.09 \pm 1.56$ & $25.74 \pm 1.18$ & $11.47 \pm 0.45$ & $9.65 \pm 1.36$ & $16.88 \pm 1.32$ & $11.43 \pm 2.77$ \\
\hline & \multicolumn{6}{|c|}{ Fatty acid composition (mean $=\mathrm{SD} \%$ ) } \\
\hline$C 8: 0$ & 0 & 0 & 0 & 0 & $0.22 \pm 0.19$ & $\theta$ \\
\hline C9:0 & 0 & 0 & 0 & 0 & 0 & 0 \\
\hline C10:0 & 0 & 0 & 0 & 0 & $v$ & 1) \\
\hline C11:0 & $0.47 \div 0.25$ & $0.73 \div 0.04$ & $\theta$ & 0 & u & is \\
\hline $\mathrm{C} 12: 0$ & $0.17 \pm 0.03$ & 0 & 0 & $\theta$ & v & ) \\
\hline C13:0 & $0.93 \pm 0.22$ & $1.28 \pm 0.22$ & 0 & 0 & $0.75 \pm 0.16$ & 1) \\
\hline C14:0 & $6.02 \pm 0.06$ & $4.50 \pm 0.37$ & $4.77 \pm 0.56$ & $6.68 \pm 1.32$ & $6.38 \neq 0.52$ & $6.55 * 2.35$ \\
\hline C15:0 & 0 & 0 & 0 & 0 & $0.49 \pm 0.01$ & 0 \\
\hline $\mathrm{C} 16: 0$ & $45.25 \pm 1.11$ & $48.42 \pm 3.48$ & $41.51 \neq 1.18$ & $41.31 \approx 0.28$ & $39.08 \div 1.75$ & $+2.39 \pm 6.76$ \\
\hline $\mathrm{C} 17: 0$ & $7.93 \pm 0.07$ & $3.07 \pm .50$ & 0 & 0 & $0.45 \pm 0.10$ & 0 \\
\hline C18:0 & $1.94 \pm 0.20$ & $.3 .93 \pm 1.48$ & $15.06 \div 0.50$ & $12.96 \pm 0.12$ & $21.53 \pm 0.67$ & $10.60 \pm 0.55$ \\
\hline $\mathrm{C} 18: 1$ & $7.09 \pm 0.15$ & $6.27 \pm 0.47$ & $5.48 \pm 0.39$ & $4.69 \pm 0.77$ & $3.24 \pm 0.17$ & $3.68+1.58$ \\
\hline C18:2 & $1.02 \times 0.04$ & $1.24 \pm 0.17$ & $8.63 \div 0.27$ & $5.47 * 0.39$ & $2.152=0.19$ & $2.91 \pm 11.2$ \\
\hline C18:3 & $13.65 \pm 0.23$ & $9.60 \pm 1.08$ & $3,67 \pm 0,10$ & $3.77 \pm 0.14$ & $4.34 \times 0.19$ & $1.39 \pm 1.29$ \\
\hline C19:0 & $2.18 \pm 0.07$ & $1.85 \pm 3.06$ & 0 & 0 & (1) & 0 \\
\hline $\mathrm{C} 20: 0$ & 0 & 0 & 0 & 0 & $1.22 \times 11.04$ & 0 \\
\hline $\mathrm{C} 20: 1$ & 0 & 0 & 0 & 0 & 0 & 0 \\
\hline $\mathrm{C2O}: 4$ & $1.59 \pm 0.24$ & $7.31 \pm 0.40$ & $12.77 \pm 0.88$ & $14.43 \pm 0.83$ & $5.45 \pm 0.34$ & $0.88 \pm 2.55$ \\
\hline C20:5 & $5.37 \pm 0.34$ & $2.76 \pm 0.36$ & $3.69 \pm 0.65$ & $3.75 \pm 0.29$ & $1.30 \pm 12,06$ & $8.09 \neq 1.76$ \\
\hline $\mathrm{C} 22: 0$ & 0 & 0 & 0 & 0 & 0 & 0 \\
\hline $\mathrm{C} 22: 1$ & 0 & $1.72 \times 2.38$ & 0 & 0 & $0.32 \pm 0.29$ & " \\
\hline $\mathrm{C} 22: 6$ & 0 & 0 & 0 & 0 & 0 & 0 \\
\hline $\mathrm{C} 24: 0$ & $1.29 \pm 0.34$ & $1.92 \pm 0.46$ & 0 & 0 & 0 & 0 \\
\hline $\mathrm{C} 24: 1$ & 0 & 0 & 0 & 0 & 0 & 0 \\
\hline Others & $5.11 \pm 0.17$ & $5.41 \pm 0.59$ & $4.41 \pm 0.51$ & $6.93 \pm 0.57$ & $12.46 \pm 2.44$ & $14.51=4,1.3$ \\
\hline
\end{tabular}

All of seaweeds had moisture contents around $85 \%$. The ash content in PA was higher than other seaweeds, 
and the lowest content was found in CR. The fat content were quite varying, with values ranges $0.15-2.26 \%$. CS had the highest content of protein (3.05\%). There was no copper in all of seaweeds samples, except only SP having trace amount. The contents of minerals were dominated by calcium, potassium and sodium. Palmitic acid (C16:0) was the main fatty acid found all of seaweeds. The distributions of dietary fiber and catechins of the Indonesian edible seaweeds are shown in Table 2.

Table 2 Dietary fiber and catechin contents of Indonesian edible seaweeds.

\begin{tabular}{|c|c|c|c|c|c|c|}
\hline & \multicolumn{6}{|c|}{ Seaweeds Species } \\
\hline & $\mathrm{CS}$ & $\mathrm{CR}$ & TC & $\mathrm{SP}$ & $\mathrm{PA}$ & $\mathrm{KA}$ \\
\hline & \multicolumn{6}{|c|}{ Dietary fiber contents (mean \pm SD g/100 g dry weight) } \\
\hline TDF & $61.8=1.4$ & $64.9 \pm 4.4$ & $63.7 \pm 3.6$ & $65.7 \pm 0.6$ & $56.6 \pm 6.6$ & $69.3 \pm 1.8$ \\
\hline IDF & $60.1 \pm 0.7$ & $64.1=3.8$ & $61.0 \pm 4.6$ & $63.5 \pm 0.9$ & $51.7 \pm 4.7$ & $58.6 \pm 2.7$ \\
\hline \multirow[t]{2}{*}{ SDF } & $1.4 \pm 0.8$ & $0.9=0.6$ & $2.6 \pm 1.0$ & $2.3 \pm 0.4$ & $4.9 \pm 2.1$ & $10.7 \pm 1.9$ \\
\hline & \multicolumn{6}{|c|}{ Catechin contents (mean \pm SD $\mu \mathrm{g} / \mathrm{g}$ dry weight) } \\
\hline GC & $98 \pm 19$ & - & - &. & - & - \\
\hline EGC & - & - & $170 \pm 49$ & $18 \pm 16$ & - & - \\
\hline $\mathrm{C}$ & - & - & + & - & $52 \pm 25$ & - \\
\hline $\mathrm{EC}$ & $91 \pm 33$ & - & + & - & + & - \\
\hline $\mathrm{EGCO}_{\mathrm{g}}$ & - & - & . & - & - & . \\
\hline $\mathrm{GCg}$ & - & - & . & . & - & * \\
\hline $\mathrm{ECg}$ & - & - & - & + & - & * \\
\hline $\mathrm{Cg}$ & $17 \pm 9$ & - & - & - & - & - \\
\hline
\end{tabular}

Notes: TDF: total dietary tiber, IDF: insoluble dietary tiber, SDF: soluble dietary fiber, GC: gallocatechin, EGC: cpigallocatechin, C: catechin, EC: epicatechin, EGCg: epigallocatechin gallate, GCg: gallocatechin gallate, ECg: epicatechin gallate, $\mathrm{Cg}$ : catechin gallate, $-:$ not detected + : trace amount

SDF and TDF levels in KA were higher than other seaweeds, but the content of IDF was lower than another seaweed, except PA. CR had the highest content of IDF. CR and KA did not contain catechin and its isomers, whereas CS contained $\mathrm{GC}, \mathrm{EC}$ and $\mathrm{Cg}$. EGC was found in TC and SP, and C in PA.

\section{DISCUSSION}

The proximate compositions of Indonesian edible seaweeds were almost same to Japanese edible seaweeds like Hizikia fusiformis, Undaria pinnatifida. ${ }^{13)}$ Furthermore, the main mineral contents of Japanese edible seaweeds were also the same; they contained sodium, potassium and calcium, whereas the contents of iron and zinc were higher than Indonesian edible seaweeds. ${ }^{13)}$

The main fatty acid of Indonesian seaweed was palmitic acids. It was the same to Japanese seaweeds Laminaria japonica, Hizikia fusiformis and Undaria pinnatifida ${ }^{\text {(3) }}$ but different from another Japanese seaweed Porphyra yezoensis, in which eicosapentaenoic acid was found as a main fatty acid. ${ }^{14)}$

The contents of SDF in Indonesian seaweed (0.9$10.7 \mathrm{~g}$ ) was lower than those in Japanese seaweed (7.1-25.1g). ${ }^{4)}$ On the contrary, Indonesian seaweeds had higher IDF content than Japanese seaweeds.
The distribution of catechin in Indonesian $\mathrm{CR}$ was similar to Japanese CR and $C$ serrulata, ${ }^{5)}$ and they did not contain catechin and its isomers. The content of EGC in SP and TC were lower than Japanese Sargassum and Turbinaria genus, and also the content of $\mathrm{C}$ in PA was lower than that in Japanese Padina genus. ${ }^{5)}$

From the results can be concluded that Indonesian seaweeds contained the high nutritional compounds, were almost same to Japanese seaweeds, although the catechin content and its isomer were lower.

\section{REFERENCES}

1. Suzuki $T$, Nakai $K$, Yoshie $T$, Shirai $T$, Hirano $T$. Digestibility of dietary fiber in brown algae, kombu by rats. Nippon Suisan Gakkaishi 1993; 59: 879-884.

2. Yoshie Y, Suzuki T, Shirai T, Hirano T. Changes in the contents of dietary fibers, minerals, free amino acids, and fatty acids during processing of dried nori. Nippon Suisan Gakkaishi 1994; 60: 117-123.

3. Yoshie Y, Suzuki T, Shirai T, Hirano T. Effect of sodium alginate on fat content and digestive organs of rats with fatfree diet. Fisheries Sci. 1995; 61: 668-671.

4. Suzuki T, Ohsugi Y, Yoshie T, Shirai T, Hirano T. Dietary fiber content, water-holding capacity and binding capacity of seaweeds. Fisheries Sci. 1996; 62: 454-461.

5. Yoshie Y, Wang W, Petillo D, Suzuki T. Distribution of catechins in Japanese Seaweeds. Fisheries Sci. 2000; 66: 998-1000.

6. Yoshie, Y, Suzuki T. Polyphenolic compounds from seaweed: Distribution and first approach to find out useful effect as antioxidant. Proceeding of The JSPS-DGHE International Symposium on Fisheries Science in Tropical Area. Sustainable Fisheries in Asia in the New Millennium. (Eds. Carman O, Sulistiono, Purbayanto A, Suzuki T, Watanabe S, and Arimoto T). 2000: 426-431.

7. Ministry of Agriculture, Republic of Indonesia. Database of Fisheries Statistic. 2000.

8. AOAC, Official Methods of Analysis, $15^{\text {th }}$ edn. Association of Official Analytical Chemist. Arlington, VA, 1990.

9. Bligh, EG, Dyer, WJ. A rapid method of total lipid extraction and purification. Can. J. Biochem. Physiol. 1959; 37: $911-917$

10. Ikegaya K, Takayanagi $\mathrm{H}$, Anan $\mathrm{T}$. Quantitative analysis of tea constituents. Chagyo Kenkyu Hokoku 1990; 71: 43-74.

11. Terada S, Maeda Y, Masui T, Suzuki Y, Ina K. Comparison of caffeine and catechin components in infusion of various tea (green, oolong and black tea) and tea drinks. Nippon Shokuhin Kogyo Gakkaishi 1987; 34: 20-27.

12. Suematsu $S$, Hisanobu $Y$, Saigo H, Matsuda R, Komatsu $Y$. A new extraction procedure of caffeine and catechins in green tea (Studies on preservation of constituents in canned drinks part V). Nippon Shokuhin Kagaku Kogaku Kaishi 1995; 42: 419-424.

13. Standard Tables of Food Composition in Japan. Resources Council, Science and Technology Agency, Japan. 2001.

14. Standard Tables of Fat-Soluble Components in Japanese Food. Resources Council, Science and Technology Agency, Japan. Printing Bureau, The Ministry of Finance, Tokyo. 1989. 